\title{
Medicolegal implications of radial and femoral access for coronary angiography and intervention in 2016: Focus on retroperitoneal hemorrhage
}

\author{
Konstantinos V. Voudris' ${ }^{1}$, Mladen I. Vidovich ${ }^{2}$ \\ 'Department of Medicine, University of Illinois at Chicago / Advocate Christ Medical Centre, \\ Chicago, IL 60612, USA; \\ 2Division of Cardiology, University of Illinois at Chicago, Chicago, IL 60612, USA
}

\section{ABSTRACT}

Background and Objectives: Retroperitoneal hemorrhage is a rare but serious complication of transfemoral approach (TFA) and TFA percutaneous coronary intervention (PCI). Radial approach for coronary angiography and intervention (transradial approach, TRA) is associated with lower access site complications and reduced blood transfusion rates. Retroperitoneal bleeding has not been described with TRA. This study sought to evaluate the relationship between femoral access for coronary angiography (TFA) and PCl-induced retroperitoneal hemorrhage and the resulting medical litigation in the United States. Methods: From 342 lawsuit claim records identified in LexisNexis database search, 17 cases of TFA and TFAPCl-related retroperitoneal hemorrhage decided between 1995 and 2015 were included in the study. Claims were thoroughly reviewed and information about the date the case was decided, patient outcome, the plaintiff, the defendant, the claim, and the trial outcome were extracted. Results: The most common filled claim was medical malpractice $(53 \%$ of the cases), followed by wrongful death $(18 \%)$ and review of the Commissioner's decision to deny the application for supplemental security income $(12 \%)$. Forty-seven percent of the cases were won by the defense, $29 \%$ by the plaintiff, and $24 \%$ were remanded for a new trial. In $82 \%$ of the cases, physicians were sued, but only $14 \%$ of the cases were won by the plaintiff. In $59 \%$ of the claims, the patient died; however, $70 \%$ of those cases were decided in favor of the defending physician and hospital. Conclusion: Retroperitoneal hemorrhage is an uncommon complication of TFA and TFA PCI and is associated with high mortality rates. Physicians should able to identify this complication early and address it in a timely manner based on the applicable standard of care. TRA and TRA PCI is a reliable alternative and may potentially reduce medicolegal liability related to access site choice.

Address for Correspondence: Mladen I. Vidovich, MD, $840 \mathrm{~S}$ Wood St, Suite 935, Chicago, IL 60612, USA. Email: miv@uic.edu

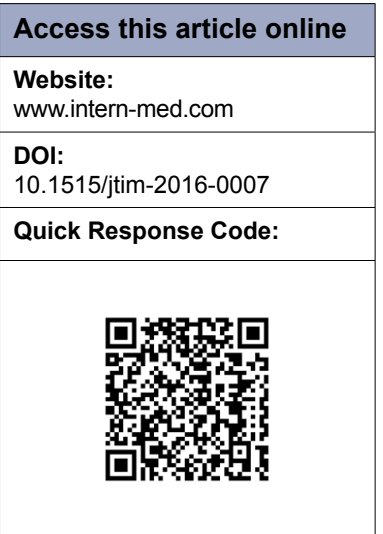

Key words: retroperitoneal hemorrhage, medical litigation, femoral arterial access, radial arterial access, diagnostic coronary angiography, percutaneous coronary intervention

\section{INTRODUCTION}

Percutaneous coronary intervention (PCI) is among the most common major medical procedures provided by the U.S. healthcare system and constitutes a significant portion of the Medicare inpatient payments to hospitals. ${ }^{[1]}$ Femoral arterial access for coronary angiography and intervention (transfemoral approach, TFA) has traditionally been the preferred access site for many operators. Risks associated with TFA PCI include access site bleeding and other major vascular complications, with retroperitoneal hematoma being one of them, leading to higher risk of subsequent morbidity, mortality, and increase in length of stay and cost. ${ }^{[2]}$ Retroperitoneal hemorrhage is an uncommon but potentially fatal complication of TFA PCI occurring in approximately $0.5-0.74 \%$ of transfemoral procedures. ${ }^{[3-4]}$ Female gender, low body surface area, chronic renal failure, use of glycoprotein IIb/IIIa inhibitors, presentation with acute myocardial infarction (MI), and high placement of the sheath (above the 
inferior epigastric artery) have been reported as the most significant risk factors for retroperitoneal hemorrhage in various studies. ${ }^{[5,6]}$ Mortality rates following retroperitoneal hemorrhage remain high, $8.6 \%$ in those experiencing a bleeding episode versus $2.4 \%$ in contemporary clinical practice, which has led to the modification of procedure strategies aiming to reduce its incidence. ${ }^{[6,7,10]}$ Transradial approach (TRA) for cardiac catheterization has consistently demonstrated significant reduction in bleeding and vascular complications as shown in multiple clinical trials ${ }^{[8-10]}$ and has led to increasing adoption of TRA worldwide. In the United States, the adoption of TRA has lagged overall and now is estimated at 30\% of all diagnostic and PCI procedures performed..$^{[1]}$

Medical malpractice litigation cases constitute an important aspect of physician daily practice with their incidence correlating to the frequency of procedures. Characteristics of medical professional liability claims in the field of cardiac catheterization have been previously described, offering invaluable advice to practicing physicians and subsequently improved patient care. ${ }^{[12]}$ As TRA completely obviates the possibility of access-related retroperitoneal bleeding, we sought to analyze the available medicolegal evidence on retroperitoneal bleeding associated with TFA. This descriptive study focuses on the medical professional liability claims associated with retroperitoneal hemorrhage following PCI and its implications on access choice in contemporary practice.

\section{MATERIALS AND METHODS}

A systemic search on The LexisNexis Academic database (LexisNexis is division of Reed Elsevier, Dayton, Ohio) ${ }^{[13]}$, a publically available and searchable archive, for published legal case opinions was performed. The combinations of keywords used were "retroperitoneal," "retroperitoneal hemorrhage," and "retroperitoneal bleeding." All cases were decided according to the US legal system from 1976 to 2015 .

After initial screening of title and summary, full text of the opinion statements considered relevant were assessed for eligibility. Criteria for including legal cases were as follows: (1) cases that involved patients who underwent diagnostic catheterization and/or PCI for any indication (primary PCI, rescue PCI, and elective PCI) and (2) cases that reported retroperitoneal hemorrhage after the respective procedure was performed. Each case was thoroughly reviewed and information about the date the case was decided, the plaintiff, the defendant, the claim, and trial outcome were extracted. Cases were further grouped and analyzed based on the patient outcome as well as on the inclusion of physician in the lawsuit.

\section{RESULTS}

From a total of 342 lawsuit claim records identified in LexisNexis database search, 17 cases of TFA and TFAPCI-related retroperitoneal hemorrhage decided between 1995 and 2015 were included in the study. The litigation characteristics and outcomes of these cases are shown in Table 1.

According to the data collected, the most commonly filled claim was medical malpractice $(52.9 \%$ of the cases), followed by wrongful death $(17.6 \%)$ and review of the Commissioner's decision to deny application for Supplemental Security Income (11.8\%). About $47.1 \%$ of the cases were won by the defense, $29.4 \%$ by the plaintiff, and $23.5 \%$ were remanded for a new trial (Table 2). PCIrelated retroperitoneal hemorrhage litigation involved the physician in $82.3 \%$ of the cases. The plaintiff won all the cases not involving the physician. However, when the physician was involved as a defendant, only $14 \%$ of the cases were won by the plaintiff.

In our study of TFA-related retroperitoneal hemorrhage, death was the most common outcome with $58.8 \%$ of the reported claims being filled by a third person acting as an executor of the deceased estate (Figure 1). Physicians and the hospital were included in the lawsuit in all of the cases. Interestingly, only one case was decided in favor of the plaintiff and two cases were remanded for a new trial. The remaining $70 \%$ of the cases were decided in favor of the defending physician and hospital, suggesting that patient outcome did not seem to influence the verdict in the plaintiff's favor (Figure 2).

Medical litigation involved judgments and rulings at numerous levels of the US legal system. In $23.5 \%$ of the cases, the decision was made at the District Court, $41.2 \%$ were decided at the Court of Appeals, 5.9\% at the Common Pleas Court, and $11.8 \%$ at the Superior Court. Furthermore, $17.6 \%$ of the claims required a Supreme Court ruling.

\section{DISCUSSION}

In this analysis of the LexisNexis Academic database, we have demonstrated for the first time the medicolegal implications and outcomes of retroperitoneal hemorrhage following TFA and TFA PCI in the United States from 1995 to 2015.

Health-care-related litigation affects physicians in many countries around the world either as an existing or emerging issue. The fear of legal action is ubiquitous in daily medical practice, and its impact is acute among medical service 
Voudris and Vidovich: Medicolegal implications of radial and femoral access for coronary angiography and intervention

\begin{tabular}{|c|c|c|c|c|c|c|}
\hline Case & Year & $\begin{array}{l}\text { Patient } \\
\text { status }\end{array}$ & Sued & Reason & Outcome & Court site \\
\hline $\begin{array}{l}\text { Horwitz vs. } \\
\text { Yale New } \\
\text { Haven Hosp. }\end{array}$ & 1996 & Died & Hospital and Physician & Medical Malpractice Claim & $\begin{array}{l}\text { Defendants did not deviate } \\
\text { from the applicable } \\
\text { standard of care }\end{array}$ & $\begin{array}{l}\text { Superior Court of } \\
\text { Connecticut }\end{array}$ \\
\hline $\begin{array}{l}\text { Woodmancy } \\
\text { vs. Colvin }\end{array}$ & 2013 & Alive & $\begin{array}{l}\text { Commissioner of } \\
\text { the Social Security } \\
\text { Administration }\end{array}$ & $\begin{array}{l}\text { Review of Commissioner's } \\
\text { decision to deny her } \\
\text { applications for disability } \\
\text { insurance benefits and } \\
\text { for Supplemental Security } \\
\text { Income (SSI) benefits }\end{array}$ & $\begin{array}{l}\text { Commissioner of Social } \\
\text { Security's decision is } \\
\text { reversed. }\end{array}$ & $\begin{array}{l}\text { Nebraska District } \\
\text { Court }\end{array}$ \\
\hline $\begin{array}{l}\text { Young vs. } \\
\text { Thota }\end{array}$ & 2013 & Died & Hospital and Physician & Medical Malpractice Claim & $\begin{array}{l}\text { Defendants did not deviate } \\
\text { from the applicable } \\
\text { standard of care }\end{array}$ & $\begin{array}{l}\text { Court of Appeals } \\
\text { Texas }\end{array}$ \\
\hline $\begin{array}{l}\text { Nelson vs. } \\
\text { Waxman }\end{array}$ & 1999 & Died & Hospital and Physician & Wrongful death claim & $\begin{array}{l}\text { Judgment of the trial court } \\
\text { is reversed, and the case is } \\
\text { remanded for a new trial }\end{array}$ & $\begin{array}{l}\text { Court of Appeals } \\
\text { Missouri }\end{array}$ \\
\hline $\begin{array}{l}\text { Johnson vs. } \\
\text { Genesis Med. } \\
\text { Ctr. }\end{array}$ & 2004 & Died & $\begin{array}{l}\text { Hospital, Physician and } \\
\text { Nurse }\end{array}$ & $\begin{array}{l}\text { Survival and wrongful death } \\
\text { claim }\end{array}$ & $\begin{array}{l}\text { Defendants did not deviate } \\
\text { from the applicable } \\
\text { standard of care }\end{array}$ & $\begin{array}{l}\text { Court of Appeals } \\
\text { lowa }\end{array}$ \\
\hline $\begin{array}{l}\text { Comstock vs. } \\
\text { Astrue }\end{array}$ & 2013 & Alive & $\begin{array}{l}\text { Commissioner of Social } \\
\text { Security Administration }\end{array}$ & $\begin{array}{l}\text { Review of the } \\
\text { Commissioner's decision } \\
\text { to deny her applications } \\
\text { for Supplemental Security } \\
\text { Income (SSI) benefits }\end{array}$ & $\begin{array}{l}\text { Commissioner's decision } \\
\text { is reversed and this case } \\
\text { is remanded for further } \\
\text { proceedings }\end{array}$ & $\begin{array}{l}\text { Northern lowa } \\
\text { District Court }\end{array}$ \\
\hline $\begin{array}{l}\text { Kapacs vs. } \\
\text { Martin }\end{array}$ & 2005 & Died & Hospital and Physician & $\begin{array}{l}\text { Wrongful Death, Survival } \\
\text { Action and Negligent } \\
\text { Infliction of Emotional } \\
\text { Distress }\end{array}$ & $\begin{array}{l}\text { 1.Defendants' Preliminary } \\
\text { Objections in the form of a } \\
\text { Motion to Strike or in the } \\
\text { alternative is SUSTAINED } \\
\text { 2. Defendants' Preliminary } \\
\text { Objections to the Plaintiffs' } \\
\text { claim for punitive } \\
\text { damages both individually } \\
\text { and vicariously are } \\
\text { OVERRULED } \\
\text { 3. Defendants' Preliminary } \\
\text { Objections to the Plaintiffs } \\
\text { claim for Negligent } \\
\text { Infliction of Emotional } \\
\text { Distress are OVERRULED } \\
\text { 4. The Defendants', } \\
\text { Preliminary Objections } \\
\text { to the Plaintiffs' claim of } \\
\text { corporate negligence are } \\
\text { SUSTAINED. }\end{array}$ & $\begin{array}{l}\text { Common } \\
\text { Pleas Court of } \\
\text { Lackawanna } \\
\text { County } \\
\end{array}$ \\
\hline $\begin{array}{l}\text { Baxter vs. } \\
\text { Cardiology } \\
\text { Assocs. }\end{array}$ & 1995 & Died & Hospital and Physician & Medical Malpractice Claim & $\begin{array}{l}\text { Patient died as a result of } \\
\text { the professional negligence }\end{array}$ & $\begin{array}{l}\text { Superior Court of } \\
\text { Connecticut }\end{array}$ \\
\hline $\begin{array}{l}\text { Sheila Orta } \\
\text { Tellado vs. } \\
\text { Saurin }\end{array}$ & 2009 & Died & Hospital and Physician & Medical Malpractice Claim & $\begin{array}{l}\text { Defendants did not deviate } \\
\text { from the applicable } \\
\text { standard of care }\end{array}$ & $\begin{array}{l}\text { Court of Appeals } \\
\text { Massachusetts }\end{array}$ \\
\hline $\begin{array}{l}\text { Snyder vs. } \\
\text { George } \\
\text { Washington } \\
\text { Univ. }\end{array}$ & 2006 & Alive & $\begin{array}{l}\text { Hospital, Physician } \\
\text { and other medical } \\
\text { employees }\end{array}$ & Medical Malpractice Claim & $\begin{array}{l}\text { Reverse the judgment of } \\
\text { the trial court and remand } \\
\text { this case for a new trial }\end{array}$ & $\begin{array}{l}\text { District of } \\
\text { Columbia Court of } \\
\text { Appeals }\end{array}$ \\
\hline $\begin{array}{l}\text { Talmore vs. } \\
\text { Baptist Hosps. } \\
\text { of Southeast } \\
\text { Tex. }\end{array}$ & 2006 & Died & Hospital and Physician & Healthcare Liability Suit & $\begin{array}{l}\text { The written expert reports } \\
\text { was not adequate and } \\
\text { claim was dismissed }\end{array}$ & $\begin{array}{l}\text { Court of Appeals } \\
\text { Texas }\end{array}$ \\
\hline $\begin{array}{l}\text { Bradshaw } \\
\text { vs. Lenox Hill } \\
\text { Hosp. }\end{array}$ & 2015 & Alive & $\begin{array}{l}\text { Hospital, Physician and } \\
\text { Nurse }\end{array}$ & Medical Malpractice Claim & $\begin{array}{l}\text { Case is remanded for a } \\
\text { new trial }\end{array}$ & $\begin{array}{l}\text { Supreme Court } \\
\text { of New York } \\
\text { Appellate Division }\end{array}$ \\
\hline $\begin{array}{l}\text { Neal vs. Sparks } \\
\text { Reg'l Med. } \\
\text { Ctr., }\end{array}$ & 2012 & Died & $\begin{array}{l}\text { Hospital, Physician and } \\
\text { Nurse }\end{array}$ & Medical Malpractice Claim & $\begin{array}{l}\text { Summary judgment } \\
\text { awarded to the hospital }\end{array}$ & $\begin{array}{l}\text { Supreme Court of } \\
\text { Arkansas }\end{array}$ \\
\hline
\end{tabular}

To be continued... 
Voudris and Vidovich: Medicolegal implications of radial and femoral access for coronary angiography and intervention

Continued...

\begin{tabular}{|c|c|c|c|c|c|c|}
\hline Case & Year & $\begin{array}{l}\text { Patient } \\
\text { status }\end{array}$ & Sued & Reason & Outcome & Court site \\
\hline $\begin{array}{l}\text { Poliner vs. Tex. } \\
\text { Health Sys. }\end{array}$ & 2008 & & $\begin{array}{l}\text { Hospital and doctors } \\
\text { involved in peer review }\end{array}$ & $\begin{array}{l}\text { Defamation damages and } \\
\text { punitive damages for a } \\
\text { doctor and his professional } \\
\text { association }\end{array}$ & $\begin{array}{l}\text { Judgment awarded for } \\
\text { defendants }\end{array}$ & $\begin{array}{l}\text { US Court of } \\
\text { Appeals for the } \\
\text { Fifth Circuit }\end{array}$ \\
\hline $\begin{array}{l}\text { Fosse vs. } \\
\text { Pensabene, }\end{array}$ & 2005 & Died & Physician & Medical Malpractice Claim & Reverse and remand & $\begin{array}{l}\text { Appellate Court of } \\
\text { Illinois }\end{array}$ \\
\hline $\begin{array}{l}\text { Rdzanek vs. } \\
\text { Hosp. Serv. } \\
\text { Dist. \# 3, }\end{array}$ & 2004 & & $\begin{array}{l}\text { Hospital, its Board } \\
\text { of Commissioners, } \\
\text { its Medical Executive } \\
\text { Committee, and } \\
\text { the hospital's Chief } \\
\text { Executive Officer }\end{array}$ & $\begin{array}{l}\text { Violation of due process } \\
\text { rights }\end{array}$ & $\begin{array}{l}\text { Court denies plaintiff's } \\
\text { preliminary injunction } \\
\text { application and denies } \\
\text { the defendants' motion } \\
\text { to dismiss the plaintiff's } \\
\text { claim. }\end{array}$ & $\begin{array}{l}\text { Eastern Louisiana } \\
\text { District Court }\end{array}$ \\
\hline $\begin{array}{l}\text { Yates vs. Univ. } \\
\text { of W. Va. Bd. } \\
\text { of Trs. }\end{array}$ & 2001 & Alive & Hospital and Physician & Medical Malpractice Claim & $\begin{array}{l}\text { The judgment was } \\
\text { reversed and the case was } \\
\text { remanded }\end{array}$ & $\begin{array}{l}\text { Supreme Court } \\
\text { of Appeals West } \\
\text { Virginia }\end{array}$ \\
\hline
\end{tabular}

\begin{tabular}{lllll}
\hline \multicolumn{2}{l}{ Table 2: Medical litigation outcome when physician sued } \\
\hline Physician Sued & Number of Cases (\%) & Defense Won (\%) & Plaintiff Won (\%) & Remanded (\%) \\
\hline Yes & $14(82.4)$ & $8(57.1)$ & $2(14.3)$ & $4(28.6)$ \\
No & $3(17.6)$ & 0 & $3(100)$ & 0 \\
\hline
\end{tabular}

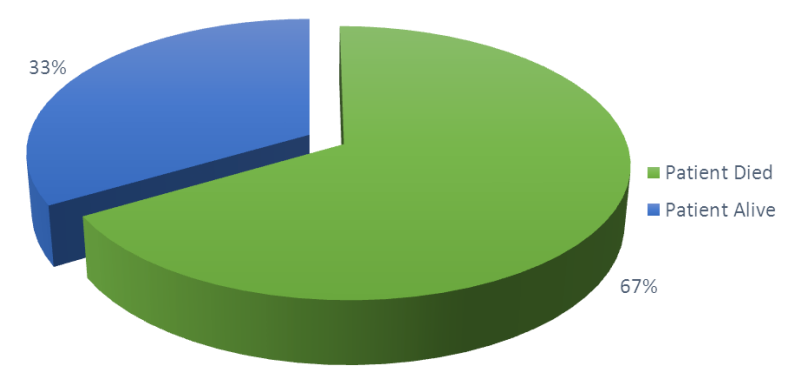

Figure 1: Patient outcomes

providers who pay increasingly high medical malpractice premiums. In 2001, physicians alone spent $\$ 6.3$ billion obtaining medical malpractice coverage. ${ }^{[14]}$ According to the American Medical Association report, physicians and institutional health-care providers in 18 states face severe challenges in obtaining affordable professional liability insurance and similar conditions are developing in another 26 states. ${ }^{[15]}$ Despite the rising interest on medical malpractice, available research data show that only a small portion of the involved patients file a legal claim and claims lacking evidence of error are not uncommon. ${ }^{[12,16]}$ Interestingly, plaintiffs win only $42 \%$ of all malpractice cases ${ }^{[17]}$ and only one-third of the cardiaccatheterization-related claims. ${ }^{[12]}$ Our findings on TFArelated retroperitoneal hemorrhage are consistent with the aforementioned observations. In our study, physicians

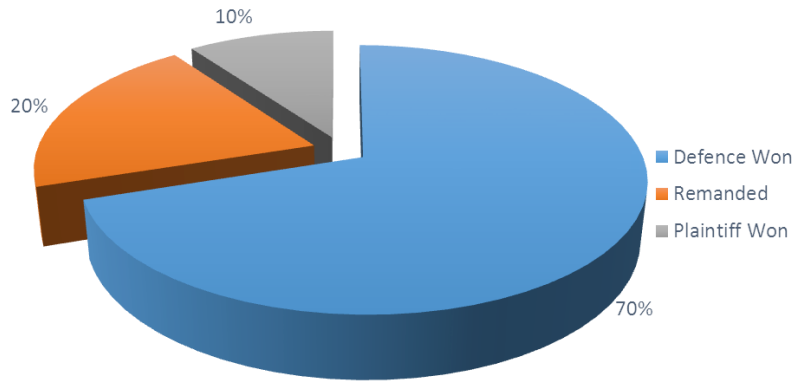

Figure 2: Litigation outcomes in deceased patient

were part of the indictment in $82.3 \%$ of the available legal claims. However, only $29.4 \%$ of the available cases were won by the plaintiff, as the remaining $71.6 \%$ case were either won by the defense $(47.1 \%)$ or were remanded for a new trial $(23.5 \%)$.

Even when identified early, retroperitoneal hemorrhage can result in high rates of morbidity and mortality regardless of the therapeutic strategy. Observed mortality rate in patients with TFA-related retroperitoneal hemorrhage has been previously reported to be $8.6 \% .^{[6,7,10]}$ Medical litigation related to in hospital mortality after TFA was significantly higher in our study, constituting $58.8 \%$ of all claims. This finding can be partially attributed to a higher tendency for family member to pursue legal advice and file a legal claim against the physician and the hospital after a 
rare yet recognized procedure-related event. Nonetheless, the observed increase in mortality did not alter the final judgment as the court favored with the defendant in 70\% of the claims. As best described in Sheila Orta-Tellado vs. Saurin Patal et al., retroperitoneal hemorrhage is a known complication of TFA and as such it should be explained to the patient before the procedure as part of the consent process. Physicians are expected to identify the complication early and act in a timely manner to treat it based on the applicable standard of care. Although the patient developed retroperitoneal hemorrhage and died shortly after undergoing cardiac catheterization, during the hearing of this case, the defendants successfully proved that all actions required to identify and treat the retroperitoneal hemorrhage were taken. Consequently, the case was decided in favor of the defendants.

This case raises the important issue of consent process in the contemporary era where TRA and TFA coexist in clinical practice. It is customary for physicians to review the known complications of diagnostic and interventional coronary procedure with the patient before the procedure. However, the access choice is almost invariably left at the physician's discretion and not explicitly discussed at the time of consent obtaining. As TRA eliminates the possibility of certain complications, specifically retroperitoneal hemorrhage, we firmly believe that in the current "post femoral era," patients should be informed about the cardinal differences between the two access site methods and consent accordingly.

In another type of case reviewed, plaintiff's vindication occurred when physicians deviated from the applicable standard of care. In Maureen Baxter et al. vs. Cardiology Associates of New Haven and Arthur the plaintiff, executrix of the estate of a patient who died after undergoing TFA filed a claim against the performing physician for medical malpractice. During the procedure, a blood vessel was perforated permitting blood to escape into the retroperitoneal area. The plaintiff claimed that the cardiologist failed to monitor, diagnose, and treat the patient's condition by not ordering and infusing blood in a timely manner and in adequate amounts. As a result of the professional negligence, the patient ultimately bled to death. During the trial, compelling data were presented supporting the accusations and subsequently resulted in the physician conviction.

While in this type of cases negligence in treatment of retroperitoneal bleeding exists, we do believe that in the future, given the availability of TRA as a safer alternative to TFA, failure to present to the patient TRA as a treatment option might similarly constitute performing physician negligence.
When the impact of practicing "defensive medicine" is considered, the economic costs are even higher both for the health system as well as for medical services consumers who face increased medical care costs. ${ }^{[18]}$ In this setting, TRA has emerged as a reliable alternative to the traditional femoral approach. TRA has been shown to reduce mortality both in ST-segment elevation myocardial infarction ${ }^{[19]}$ and non-ST-segment elevation acute coronary syndrome (NSTE ACS) ${ }^{[20]}$. Equally important, in patients with acute coronary syndromes, TRA and TRA PCI have been associated with significantly lower-access-related complication both in male as well as in female in contrast to femoral artery access. ${ }^{[21,22]}$ Blood transfusion rates have also been proven to be significantly reduced in the TRA populations, with one study reporting a $50 \%$ reduction in the blood transfusion rates when compared to TFA. ${ }^{[23]}$ These findings have led to a more widespread adoption of radial access in contemporary PCI procedures worldwide and in the United States. ${ }^{[11,24]}$

The reduction in access-related complications seen with TRA notably correlates with the reduction in retroperitoneal hemorrhage incidence. While this highly morbid complication is infrequently encountered, the expenses associated with its diagnosis and treatment are substantial. The financial repercussions extend beyond medicolegal implications and pose a great challenge for health-care providers in the United States with the implementation of the Affordable Care Act and Medicare Alternative Payment Models.

Our study has several potential limitations. It includes cases available at LexisNexis database that were decided at court. Cases settled outside court are usually not reported in the database. Reported data collection was reliant on LexisNexis database accuracy and degree of available information. Opinions provided in the database are from nonmedically trained judges.

In conclusion, retroperitoneal hemorrhage is a significant complication of TFA. Although uncommon, it is associated with high mortality rates. Practicing physicians should be able to identify this complication early and address it in a timely manner based on the applicable standard of care. When so, our current analysis shows the ruling of medical litigation to be in favor of the defending physician, irrespective of patients' mortality. TRA is a safe and effective alternative to TFA associated with reduced morality, lower access site complications rates, and reduced blood transfusion rates. In contemporary practice, TRA should be offered to patients during the consent process to avoid potential medicolegal liability. 


\section{Conflicts of Interest}

None declared.

\section{REFERENCES}

1. De Frances CJ, Lucas CA, Vuie VC, Golosinskiy A. 2006 National Hospital Discharge Survey. Hyattsville, MD: National Center for Health Statistics, 2008.

2. Doyle BJ, Rihal CS, Gastineau DA, Holmes DR Jr. Bleeding, blood transfusion, and increased mortality after percutaneous coronary intervention: implications for contemporary practice. J Am Coll Cardiol 2009;53:2019-27.

3. Farouque HM, Tremmel JA, Raissi Shabari F, Aggarwal M, Fearon WF, $\mathrm{Ng}$ MK, et al. Risk factors for the development of retroperitoneal hematoma after percutaneous coronary intervention in the era of glycoprotein IIb/IIIa inhibitors and vascular closure devices. J Am Coll Cardiol 2005;45:363-8.

4. Kent KC, Moscucci M, Mansour KA, DiMattia S, Gallagher S, Kuntz R, et al. Retroperitoneal hematoma after cardiac catheterization: Prevalence, risk factors, and optimal management. J Vasc Surg 1994;20:905-10.

5. Ellis SG, Bhatt D, Kapadia S, Lee D, Yen M, Whitlow PL. Correlates and outcomes of retroperitoneal hemorrhage complicating percutaneous coronary intervention. Catheter Cardiovasc Interv 2006;67:541-5.

6. Trimarchi S, Smith DE, Share D, Jani SM, O'Donnell M, McNamara R, et al. Retroperitoneal hematoma after percutaneous coronary intervention: Prevalence, risk factors, management, outcomes, and predictors of mortality: A report from the BMC2 (Blue Cross Blue Shield of Michigan Cardiovascular Consortium) registry. JACC Cardiovasc Interv 2010;3:845-50.

7. Maluenda G, Mitulescu L, Ben-Dor I, A Gaglia M Jr, Weissman G, Torguson $\mathrm{R}$, et al. Retroperitoneal hemorrhage after percutaneous coronary intervention in the current practice era: clinical outcomes and prognostic value of abdominal/pelvic computed tomography. Catheter Cardiovasc Interv 2012;80:29-36.

8. Kwok CS, Khan MA, Rao SV, Kinnaird T, Sperrin M, Buchan I, et al. Access and non-access site bleeding after percutaneous coronary intervention and risk of subsequent mortality and major adverse cardiovascular events: systematic review and meta-analysis. Circ Cardiovasc Interv 2015;8:e001645.

9. Jolly SS, Yusuf S, Cairns J, Niemelä K, Xavier D, Widimsky P, et al. Radial versus femoral access for coronary angiography and intervention in patients with acute coronary syndromes (RIVAL): a randomised, parallel group, multicentre trial. Lancet 2011;377:1409-20.

10. Piccolo R, Galasso G, Capuano E, De Luca S, Esposito G, Trimarco B, et al. Transradial versus transfemoral approach in patients undergoing percutaneous coronary intervention for acute coronary syndrome. A meta-analysis and trial sequential analysis of randomized controlled trials. PLoS One 2014;9:e96127

11. Feldman DN, Swaminathan RV, Kaltenbach LA, Baklanov DV, Kim LK, Wong SC, et al. Adoption of radial access and comparison of outcomes to femoral access in percutaneous coronary intervention: an updated report from the national cardiovascular data registry (2007-2012). Circulation 2013;127:2295-306.

12. Kim C, Vidovich MI. Medicolegal characteristics of cardiac catheterization litigation in the United States, 1985 to 2009. Am J Cardiol 2013;112:1662-6.

13. Lexis Nexis. Available at: http://academic.lexisnexis.com. Accessed on February 17, 2016.

14. US Department of Health and Human Services, Office of the Assistant Secretary for Planning and Evaluation. Confronting the new health care crisis: improving health care quality and lowering costs by fixing our medical liability system. July 24, 2002. Available at: http://aspe.os.dhhs. gov/dattcp/reports /litrefm.pdf. Accessed on November 13, 2005.

15. Mello MM, Studdert DM, Brennan TA. The new medical malpractice crisis. N Engl J Med 2003;349:2281-4.

16. Studdert DM, Mello MM, Gawande AA, Gandhi TK, Kachalia A, Yoon C, et al. Claims, errors, and compensation payments in medical malpractice litigation. N Engl J Med 2006;354:2024-33.

17. Michota FA, Donnelly MJ. Medicolegal issues in perioperative medicine: lessons from real cases. Cleve Clin J Med 2009;76(Suppl 4): S119-25.

18. Rubin RJ, Mendelson DN. How much does defensive medicine cost? J Am Health Policy 1994;4:7-15.

19. Romagnoli E, Biondi-Zoccai G, Sciahbasi A, Politi L, Rigattieri S, Pendenza G, et al. Radial versus femoral randomized investigation in ST-segment elevation acute coronary syndrome: the RIFLE-STEACS (Radial Versus Femoral Randomized Investigation in ST-Elevation Acute Coronary Syndrome) study. J Am Coll Cardiol 2012;60:2481-9.

20. Bavishi C, Panwar SR, Dangas GD, Barman N, Hasan CM, Baber U, et al. Meta-Analysis of Radial Versus Femoral Access for Percutaneous Coronary Interventions in Non-ST-Segment Elevation Acute Coronary Syndrome. Am J Cardiol 2016;117:172-8.

21. Ruiz-Rodriguez E, Asfour A, Lolay G, Ziada KM, Abdel-Latif AK. Systematic Review and Meta-Analysis of Major Cardiovascular Outcomes for Radial Versus Femoral Access in Patients With Acute Coronary Syndrome. South Med J 2016;109:61-76.

22. Pandie S, Mehta SR, Cantor WJ, Cheema AN, Gao P, Madan M, et al. Radial Versus Femoral Access for Coronary Angiography/Intervention in Women With Acute Coronary Syndromes: Insights From the RIVAL Trial (Radial vs femoral access for coronary intervention). JACC Cardiovasc Interv 2015;8:505-12.

23. Chase AJ, Fretz EB, Warburton WP, Klinke WP, Carere RG, Pi D, et al. Association of the arterial access site at angioplasty with transfusion and mortality: the M.O.R.T.A.L study (Mortality benefit Of Reduced Transfusion after percutaneous coronary intervention via the Arm or Leg). Heart 2008;94:1019-25.

24. Voudris KV, Georgiadou P, Charitakis K, Marmagkiolis K. Radial Interventions: Present and Future Indications. Curr Treat Options Cardiovasc Med 2016;18:2.

How to cite this article: Voudris VK, Vidovich MI. Medicolegal implications of radial and femoral access for coronary angiography and intervention in 2016: Focus on retroperitoneal hemorrhage. J Transl Intern Med 2016; 4: 29-34. 